\title{
Correlation between transverse and vertical measurements in Brazilian growing patients, evaluated by Ricketts-Faltin frontal analysis
}

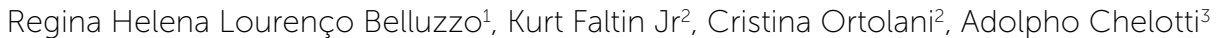

Introduction: Currently in orthodontic diagnosis, besides the lateral cephalometric analysis which evaluates the anteroposterior and vertical direction, the frontal analysis may be added, leading us to another important dimension in space: the transverse dimension. Objective: Few longitudinal samples with the frontal radiograph were published, so this cephalometric study was designed to correlate the transversal and vertical measures by Ricketts-Faltin frontal analysis into two radiographic times. Methods: The sample consisted of 45 Brazilian children, 25 girls and 20 boys, all presenting mixed dentition, with balanced facial aesthetics and no previous orthodontic/orthopedic treatment. The initial average age $\left(T_{1}\right)$ was 7.7 years and the final $\left(\mathrm{T}_{2}\right) 13.3$ years. The measurements evaluated were: FTD, MxTD, NTD, LITD, MdTD (transversal), OVD and TVD (vertical). Results: All transversal measures were positively correlated with a medium or high correlation with each other and the vertical measurements; only LITD presented a low correlation with these measurements. Conclusion: It was concluded that the face has interdependent regions and that this feature remains with growth.

Keywords: Frontal teleradiograph. Longitudinal study. Correlation.

Introdução: atualmente no diagnóstico ortodôntico, além da análise cefalométrica lateral — que avalia os sentidos anteroposterior e vertical - , deve-se acrescentar a análise no sentido frontal, a qual propicia outra dimensão importante no espaço, a transversal. Objetivo: poucas são as amostras longitudinais publicadas utilizando telerradiografias frontais; portanto, o presente estudo cefalométrico teve o intuito de correlacionar as medidas transversais e verticais por meio da análise frontal de Ricketts-Faltin, em dois tempos radiográficos. Métodos: a amostra constou de 45 crianças brasileiras, sendo 25 meninas e 20 meninos, todos apresentando dentição mista, com perfil harmonioso e sem nunca terem sido tratadas ortodonticamente e/ou ortopedicamente. A idade média inicial (T1) foi de 7,7 anos e a final (T2) de 13,3 anos. As medidas avaliadas foram: DTF, DTMx, DTN, DTII e DTMd (transversais); DVO e DVT (verticais). Resultados: todas as medidas transversais estavam correlacionadas positivamente, em grau médio ou forte, entre si e com as medidas verticais; somente DTII estava correlacionada em grau fraco com essas medidas. Conclusão: concluiu-se que a face possui regiões interdependentes, e assim mantém-se mesmo com o crescimento.

Palavras-chave: Telerradiografia frontal. Estudo longitudinal. Correlação.

${ }^{1}$ Associate Professor, Department of Orthodontics and Facial Orthopedics, UNIP.

${ }^{2}$ Full Professor, Department of Orthodontics and Facial Orthopedics, UNIP. ${ }^{3}$ Private Practice.

Submitted: April 24, 2009 - Revised and accepted:June 20, 2011
How to cite this article: Belluzzo RHL, Faltin Jr K, Ortolani C, Chelotti A. Correlation between transverse and vertical measurements in Brazilian growing patients, evaluated by Ricketts-Faltin frontal analysis. Dental Press J Orthod. 2013 Jan-Feb;18(1):50-4.

" The authors report no commercial, proprietary or financial interest in the products or companies described in this article.

Regina Helena Lourenço Belluzzo

E-mail: rebelluzzo@ortodontista.com.br 


\section{INTRODUCTION}

The study of human skulls took place since ancient times through craniometric measurements carried out on dried skulls. With the discovery of the X-rays in 1895 and its regulations in 1931, it became possible to evaluate growth changes and development of the same patient along the years with or without orthodontic treatment. ${ }^{3,8}$

From this moment onwards, interest on lateral cephalometric diagnosis started to expand. On the other hand, PA cephalometric radiographs remained stagnant over the years and currently there is still a great reluctance regarding its use. This lack of interest added to the difficulty to satisfactorily position the head on the cephalostat resulted in the small progress of the PA analysis. ${ }^{4,6,15,17,19,20,25}$ However, the need to use frontal cephalometry for a complete orthodontic diagnosis was reinforced with the development of orthodontic techniques such as palatal expansion, facial orthopedics, mandibular posture, changes in the transverse dimension through the use of braces and even with regards to the relationship between respiration and growth..$^{9,14,21,24}$

Patients are three-dimensional and not two-dimensional, therefore it is no longer acceptable that orthodontic diagnosis is made solely by considering two dimensions of space: The anteroposterior and lateral planes obtained in lateral teleradiographs. ${ }^{11,13,18}$ The great importance of expanding the vision in more than one plane of space for a complete diagnosis and orthodontic treatment was published in the book that refers to orthodontic diagnosis, specifically in the section "Three-Dimensional Cephalometric Analysis" by Langlade, where PA analysis developed by Ricketts was described, reporting its implementation, clinical standards and their respective clinical deviations. ${ }^{12}$

It is essential to remember the importance of keeping the PA cephalometric radiograph analysis associated with the lateral analysis. This is to obtain a more accurate and complete diagnosis so to increase the vision of the transverse dimension of the face, maxilla and mandible; tooth position in the lateral direction; evaluation of maxillary expansion, condylar position; functional deviations of the mandible, among many others. ${ }^{1,7,10,13,16}$

There are few longitudinal studies on posteroanterior radiographs, ${ }^{2,22}$ so the aim of this study is to broaden the understanding of the PA radiograph by directing the diagnosis to another important dimension in space: The transverse dimension.

\section{MATERIAL, METHODS AND STATISTICAL ANALYSIS}

The selected sample for this study consisted of 45 Brazilian children from São Paulo city, 25 female and 20 males attending the Children's Clinic of Paulista University, UNIP. All children initially presented in the mixed dentition, harmonic profile, satisfactory occlusion without any tooth loss and/or extensive restorations in the posterior teeth, and no previous orthodontic or orthopedic treatment. At the time when the first radiographs were taken patients had a mean age of 7 years and 7 months $\left(T_{1}\right)$, at the second, 13 years and 3 months $\left(\mathrm{T}_{2}\right)$, with a mean interval of 5 years and 8 months between the two radiographs.

All PA radiographs were taken using the same X-ray equipment. The tracings were made on a light box in a dark room, on a specific 0.003-in tracing paper and were measured twice by the same examiner, within an interval of at least 1 week to eliminate measurement inaccuracies. The cephalometric PA analysis used was the one proposed by Ricketts ${ }^{19}$ and Faltin. ${ }^{11}$

The analyzed transverse Ricketts measurements ${ }^{19}$ were: FTD (Facial Transverse Dimension), NTD (Nasal Transverse Dimension), MxTD (Maxillary Transverse Dimension), MdTD (Mandibular Transverse Dimension) and LITD (Lower Intermolar Transverse Dimension) (Fig 1).

The Faltin ${ }^{11}$ vertical measures were: OVD (Occlusal Vertical Dimension) and TVD (Total Vertical Dimension) (Fig 2).

The objective of this study was to determine the correlations of these seven orthodontic measurements carried out in two different times $\left(\mathrm{T}_{1}\right.$ and $\left.\mathrm{T}_{2}\right)$ and also to consider whether or not they were maintained with growth $\left(\mathrm{T}_{1} \times \mathrm{T}_{2}\right)$.

To evaluate the correlations at $T_{1}$ and $T_{2}$, Pearson's linear correlation coefficients were used to describe the degree of correlation between the two variables, ranging from -1 to 1 . Values near zero indicated no linear association, and values close to the extremes indicated large linear association between the variables. To evaluate whether the correlation coefficients remained at the same values between the two times, $\mathrm{T}_{1} \times \mathrm{T}_{2}$, comparing correlation coefficients tests were used. 


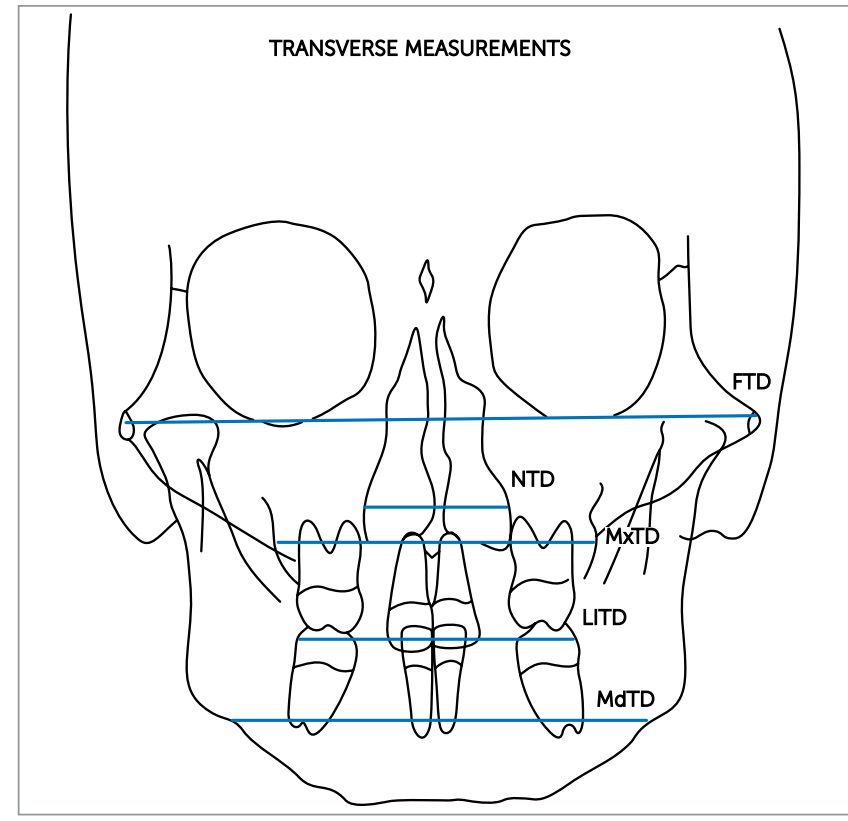

Figure 1 - Transverse measurements proposed by Ricketts.

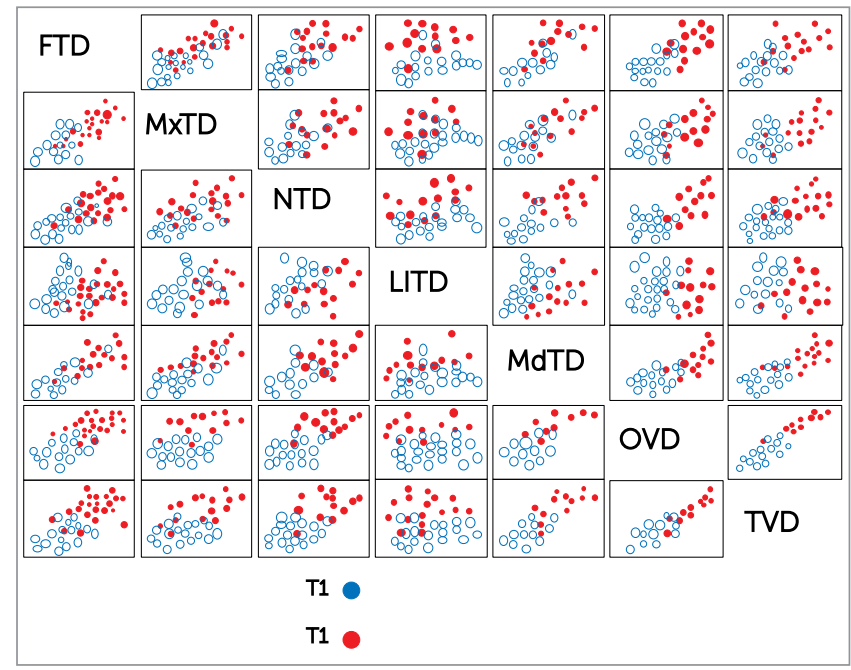

Figure 3 - Scatter plot between measurements for $T_{1}$ (blue) and for $T_{2}$ (red)

\section{RESULTS}

The Pearson's correlation coefficients are shown in Tables 1 and 2, and Table 1 shows the Person's linear Correlation indices for the $T_{1}$ measurements and Table 2 the indices for $\mathrm{T}_{2}$. Analysis of both tables shows that positive values can be observed, indicating positive correlations, i.e., when the value of a measurement increases, the other also increases. It was also noted that many values are near zero, indicating no linear correlation between the measurements.

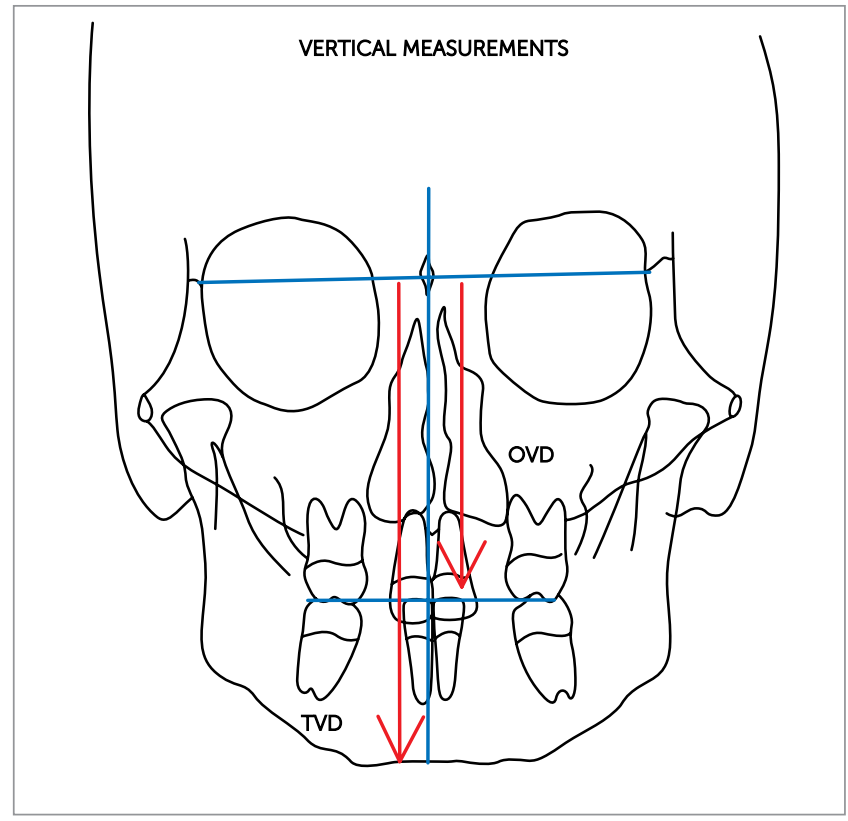

Figure 2 - Vertical measurements proposed by Faltin.

To evaluate the correlations between the variables at $\mathrm{T}_{1}$ and $\mathrm{T}_{2}$ the following correlation degrees are considered (absolute values for the correlations):

- Strong correlations: Index over 0.8;

- Average correlations: Index between 0.5 and 0.799 ;

- Weak correlations: Index between 0.3 and 0.499 ;

- Very weak correlations: Index under 0.299;

To better illustrate these correlations, Figure 3 was developed with a two by two scatter plot between variables, for $T_{1}$ and $T_{2}$, where the behavior of the measurements can be observed, for example, it shows that OVD and TVD have good positive correlation in both times (the points describe an ascending straight line), as well as with OVD and MdTD, although in this case the data are slightly more scattered.

To verify whether the correlation coefficients would change between the two times, tests were carried out to compare the linear correlation coefficients between Time 1 and 2, which results are shown in Table 3.

\section{DISCUSSION}

The first studies using frontal and lateral cephalometric radiographs were only possible in 1931, after the simultaneous publication in Germany and the U.S.A., time when the cephalometric radiography was standardized. ${ }^{3,8}$ 
Table 1 - Pearson's Linear Correlation for the measurements at $T_{1}$.

\begin{tabular}{lllllll}
\hline & FTD & MxTD & NTD & LITD & MdTD & OVD \\
MxTD & 0.640 & & & & & \\
NTD & 0.429 & 0.494 & & & & \\
LITD & 0.284 & 0.445 & 0.414 & & & \\
MdTD & 0.703 & 0.684 & 0.495 & 0.320 & & \\
OVD & 0.470 & 0.387 & 0.320 & 0.180 & 0.434 & \\
TVD & 0.427 & 0.407 & 0.374 & 0.349 & 0.512 & 0.786 \\
\hline
\end{tabular}

Table 3 - Correlation indexes, which were altered significantly between the two times.

\begin{tabular}{llll}
\hline & Time 1 & Time 2 & Correlation \\
\hline TVD x OVD & 0.786 & 0.908 & Increased \\
\hline
\end{tabular}

Several cephalometric PA analysis were developed, but the most commonly used was the one proposed by Ricketts. ${ }^{19}$ Since this analysis was based on a sample of Caucasian North American patients, other authors had interest in verifying the applicability of the reference values of the Ricketts' PA analysis in other populations, such as Chinese, Japanese, Brazilian and Austrian. ${ }^{5,14,20,21,23}$

However, when searching for longitudinal studies related to the PA radiograph, it appears that only few studies were carried out.,22

In this study seven measures of cephalometric PA analysis proposed by Ricketts ${ }^{19}$ and Faltin ${ }^{11}$ in two radiographic times $\left(T_{1}\right.$ and $\left.T_{2}\right)$ were correlated. It was also evaluated whether these correlations have changed during the follow-up period of this study, mean time 5 years and 8 months.

FTD is related to facial width in the lateral direction, confirming that other measurements, which also represent the transverse direction were positively correlated at a significant level of $95 \%$ in an average degree. This was also positive for MxTD, MdTD, both in $T_{1}$ and $T_{2}$, except LITD where there was no significant correlation, probably because this was the only dental measurement. When FTD was correlated with the vertical measurements, OVD and TVD, both were also positively correlated, at a significant level of $95 \%$, but in a weaker degree.

MxTD is related to the width of maxillary bone, confirming that only MdTD had an average positive
Table 2 - Pearson's Linear Correlation for the measurements at $T_{2}$.

\begin{tabular}{lllllll}
\hline & FTD & MxTD & NTD & LITD & MdTD & OVD \\
MxTD & 0.707 & & & & & \\
NTD & 0.449 & 0.440 & & & & \\
LITD & 0.421 & 0.486 & 0.551 & & & \\
MdTD & 0.609 & 0.633 & 0.466 & 0.400 & & \\
OVD & 0.456 & 0.508 & 0.409 & 0.142 & 0.613 & \\
TVD & 0.440 & 0.536 & 0.408 & 0.158 & 0.618 & 0.908 \\
\hline
\end{tabular}

correlation in $T_{1}$ and $T_{2}$. Vertically, OVD and TVD, were positively correlated, increasing from weak in $T_{1}$ to average degree in $T_{2}$. This shows that with growth the correlation among these measurements became stronger.

NTD is related to the nasal width and consequently to the patient's respiratory capacity. The maxillary atresia is strongly correlated with the respiratory capacity of the upper airways, where the lack of airflow through the nose and thus the opening of the mouth and the lowering of the tongue reduce the stimulation of transverse maxillary growth. The diagnosis of the maxillary width is extremely important to establish a potential prognosis. A weak positive correlation in all transverse and vertical measurements was found. These correlations increased in $T_{2}$, showing that in this sample this measurement has an independent characteristic, probably because the patients presented with no transverse maxillary deficiency.

LITD is the only dental measurement in this study. The LITD analysis is very important as it gives the value of the width of the lower arch. This variable had a weak or very weak significant correlation with the variables studied. These relations were maintained with growth. This is probably due to their characteristic behavior during the development of the occlusion, as this measurement decreases during growth through the lingual inclination of the molars, which compensates in width the mandibular growth.

MdTD represents the transverse bone width of the mandible, and its importance in the differential diagnosis of orthognathic surgery is essential. This provides the real value of the mandibular width, which may be correlated with the maxillary width, so to precisely verify where the problem lies. MdTD had an average positive correlation with the transverse measures FTD, 
MxTD, and with the vertical OVD and TVD. These correlations remained in $\mathrm{T}_{2}$.

OVD represents the height of the average face in vertical direction, and as seen previously, this variable has a weak or medium positive correlation with all transverse and vertical studied measures, both in $\mathrm{T}_{1}$ and $\mathrm{T}_{2}$, except with LITD, which presented a very weak positive correlation. However, there was a strong correlation, the largest found in this study, with the variable TVD, increasing with growth.

TVD provides the total height of the face in the vertical direction. This variable has an average positive correlation with all transverse and vertical studied measurements presenting a strong positive correlation with the variable OVD, except with LITD, which proved to be weakly positive correlated.

REFERENCES

1. Araujo TM, Wilhelm RS, Almeida MA. Skeletal and dental arch assymmetries in Class II division 1 subdivision malocclusions. J Clin Pediatr Dent. 1994;18(3):181-5

2. Athanasiou $A E$, Droschl $H$, Bosch $C$. Data and patterns of transverse dentofacial structure of 6- to 15-year-old children: A posteroanterior cephalometric study. Am J Orthod Dentofacial Orthop. 1992;101(5):465-71.

3. Broadbent $\mathrm{BH}$. A new $\mathrm{x}$-ray technique and its application to orthodontia Angle Orthod. 1931:1(2):45-66

4. Broadbent $\mathrm{BH}$. Bolton standards and technique in orthodontic practice. Angle Orthod. 1937:4(7):209-33

5. Engel G, Spolter BM. Cephalometric and visual norms for a Japanese population. Am J Orthod. 1981;80(1):48-60

6. Ghafari J, Cater PE, Shofer FS. Standardizing film distance on cephalometric measurements. Am J Orthod Dentofacial Orthop. 1995:108(1):30-7.

7. Grummons DC, Van de Coppello K. A frontal assymmetry analysis. J Clin Orthod. 1987:21(7):448-65

8. Hofrath $\mathrm{H}$. Die bedeutung der rontgenfern und abstrandsaufnahme fur die diagnostik der kieferanomalien. Fortschritte der Orthodontik.1931:1:232-58.

9. Huertas D, Ghafari J. New posteroanterior cephalometric norms: A comparison with craniofacial measures of children treated with palatal expansion. Angle Orthod. 2001;71(4):285-92.

10. Janson GR, Metaxas A, Woodside DG, de Freitas MR, Pinzan A. Three-dimensional evaluation of skeletal and dental asymmetries in Class II subdivision malocclusions. Am J Orthod Dentofacial Orthop. 2001:119(4):406-18

11. Faltin Jr K. Diagnóstico Ortodôntico - Aula: análise cefalométrica frontal de Ricketts-Faltin. Comunicação pessoal. Universidade Paulista, Instituto de Ciências e Saúde, Faculdade de Odontologia; 1999

12. Langlade M. Diagnóstico ortodôntico. São Paulo: Ed. Santos; 1993. p. 193-204.
This indicates that the transverse measurements of the face are interrelated and this interrelationship between them is maintained or increases with growth. LITD is a dental measurement, which showed to behave independently from bone measurements. OVD and TVD were measurements that had the highest correlation in this study, showing that the face, further than the transverse growth, has an important dimension to be considered, the vertical one.

\section{CONCLUSION}

In view of the obtained results from the studied sample, we may conclude that the face retains interdependent regions that correlate positively with each other, both transversely and vertically, and these relationships are maintained or strengthened with growth.
13. Lundstr MA. Some assymmetries of the dental arches, jaws, and skull, and their etiological significance. Am J Orthod. 1961;47(2):81-106.

14. Michelon D. Estudo de grandezas cefalométricas em telerradiografias em norma frontal [tese]. Piracicaba (SP): Universidade Estadual de Campinas: 1999

15. Mulick JF. Clinical use of the frontal headfilm. Angle Orthod. 1965;35(4):299304

16. Peck S, Peck L, Kataja M. Skeletal assymmetry in esthetically pleasing faces. Angle Orthod. 1991;61(1):43-8

17. Richardson ME. The reproducibility of measurements on depressed posteroanterior cephalometric radiographs. Angle Orthod. 1967;37(1):48-51

18. Ricketts RM. Perspectives in the clinical application of cephalometrics - The first fifty years. Angle Orthod. 1981;51(2):115-50

19. Ricketts RM. Orthodontic diagnosis and planning cephalometric systems. St Louis: Rocky Mountain; 1982

20. Sato K. Estudo cefalométrico radiográfico de padrões crânio-faciais, em normas lateral e frontal, em adolescentes brasileiros, leucodermas, com oclusão dentária normal [tese]. São Paulo (SP): Universidade de São Paulo; 1982

21. Silva JJ, Oliveira MG. Estudo cefalométrico computadorizado, em norma frontal, de dimensões lineares e angulares em indivíduos da raça negra. Rev Fac Odontol Porto Alegre. 1997:38(1):7-11

22. Snodell SF, Nanda RS, Currier GF. A longitudinal cephalometric study of transverse and vertical craniofacial growth. Am J Orthod Dentofacial Orthop. 1993:104(5):471-83

23. Vasconcellos FAF. Avaliação das assimetrias faciais em traçados cefalométricos obtidos por meio de telerradiografias em norma frontal de pacientes leucodermas brasileiros com oclusão normal [dissertação]. São Paulo (SP): Universidade de São Paulo; 2001.

24. Wei SHY. Craniofacial width dimensions. Angle Orthod. 1970:40(2):141-9.

25. Yoon YJ, Kim DH, Yu PS, Kim HJ, Choi EH, Kim KW. Effect of head rotation on posteroanterior cephalometric radiographs. Angle Orthod. 2002;72(1):36-42. 